\title{
Immunological mechanisms in drug-induced blood dyscrasias
}

\author{
URS NYDEGGER AND PETER A. MIESCHER
}

From the Division of Haematology, Department of Medicine, University of Geneva, Geneva, Switzerland

Drugs can produce blood disorders in many ways. At one end of the spectrum are dose-dependent effects which can be explained in pharmacological terms as 'toxic' reactions. At the other end of the spectrum are dose-independent effects which cannot be predicted. With the discovery of the causal relationship between amidopyrine intake and agranulocytosis in certain patients, increasing attention has been paid to the latter phenomena and a number of distinct immune mechanisms have been elucidated in drug-induced blood dyscrasias.

The first mechanism is similar to that encountered in experimental serum sickness (Cochrane and Koffler, 1973). The thrombocytopenia and leucopenia in this condition is probably due to the effect of immune complexes on the cells: platelets and leucocytes, coated with antigen-antibody complexes, are eliminated from the circulating blood, presumably through phagocytosis by the reticuloendothelial system (Miescher, 1955; Mannick Haakenstad, and Arend, 1974). A similar immunecomplex type mechanism is likely to be operative in many cases of drug-induced thrombocytopenia and leucopenia.

The second mechanism has been used for many years as a serological tool for the detection of antibodies and is the agglutination of antigen-coated red cells by antibody (passive hemagglutination). Damage to drug-coated cells by drug-specific antibodies is today a well recognized mechanism in certain drug-induced cytopenias.

A third mechanism emerged from the clinical observation that certain drugs lead to the development of autoantibodies, ie, antibodies directed to autologous antigenic determinants.

In this review, these three mechanisms are discussed first and serological methods available for diagnosis of immune drug-induced blood dyscrasias will be discussed later.

\section{Immune-complex-mediated Cell Damage}

In 1949, Ackroyd (1964, review) discovered a number of in-vitro reactions suggesting that platelet dam- age in Sedormid-(allylisopropylcarbamide)-induced thrombocytopenia might be mediated by Sedormid/ antibody complexes, although at that time he came to a different conclusion. Soon after, Moeschlin and Wagner (1952) observed analogous in-vitro phenomena with the serum of a patient suffering from amidopyrine-induced agranulocytosis, but again the pathogenesis underlying this observation was interpreted in a different way. Shulman's studies (1958), as well as our own (Miescher, 1955), have suggested that formation of immune complexes and their subsequent deposition on the cells are most likely to be operative in this type of cytopenia although a number of pertinent questions are still unanswered:

1 Why should one particular drug always produce thrombocytopenia when complexed with an antibody and another drug always produce agranulocytosis?

2 Why is the disappearance of platelets or leucocytes from the peripheral blood almost complete, whereas experimental serum sickness is only associated with a slight degree of thrombocytopenia and leucopenia?

3 Why are the precursor cells within the bone marrow affected so greatly in this type of agranulocytosis?

Various observations might help to answer the first question. In the case of Sedormid, it was shown that the drug concentrated around platelets without being strongly attached. Furthermore, it was shown that the drug could be washed off the platelets very easily. This affinity of Sedormid for platelets may favour the attachment of the drug-antibody-complexes to the cells. In the case of drugs shown to induce thrombocytopenia in some patients and immune haemolytic anaemia in others, Shulman (1963) was able to demonstrate that thrombocytopenia was usually mediated by IgG antidrug antibodies whereas immune haemolytic anaemia was usually mediated by IgM antidrug antibodies. From this observation it was suggested that the type of antibody involved in the formation of immune complexes may also be relevant for the cell specificity of the reaction and it might be postulated that this specificity is related to 46 
the cell surface receptors (Nussenzweig, Lay, and Miescher, 1969). However, this question is still wide open to further investigation, particularly when drugs are the antigen or the hapten involved.

The question of why granulocytes and/or platelets almost totally disappear from the peripheral blood in drug-induced agranulocytosis and/or thrombocytopenia and are frequently associated with a gradual disappearance of the precursor cells is equally difficult to answer. In this context, one should bear in mind that agents which raise the intracellular level of cyclic AMP, such as theophyllin or prostaglandin $E_{1}$, have been implicated in additional damage to subcellular organelles (Gillespie, 1971). Thus drug/ antibody complexes might be harmful to blood cells through at least two pathways, first because the complex coats the cells and secondly because of the potentiated toxic effect of the antigen.

The removal of large quantities of cells from the circulating blood with special procedures (leucopheresis, thrombocytopheresis) does not lead to damage to the precursor cells and, in experimental serum sickness, neutropenia is not accompanied by damage to the cells in the bone marrow. However, in many drug-induced leucopenias, drug-mediated damage is not limited to circulating cells but affects precursor cells as well. The pathogenesis of the bone marrow damage has not yet been elucidated but a number of differing mechanisms may be operative. The recovery time of agranulocytosis not only varies with the extent of cell damage in the bone marrow (injury to myelocytes, promyelocytes or myeloblasts), but also with the pharmacological variety of drugs involved, ie, being relatively short with amidopyrine and much longer with phenothiazines.

\section{Damage to Drug-coated Cells by Drug-specific Antibodies}

This mechanism was first demonstrated in penicillininduced immune haemolytic anaemia. Evidence has been provided that part of the immunogenicity of benzylpenicillin is due to a rearrangement of its isomer D-benzylpenicillenic acid, a compound which is chemically highly reactive with proteins. Levine and Redmond (1967) could demonstrate that $30 \%$ of patients taking $1 \cdot 2-2 \cdot 4$ million units of penicillin had some detectable drug on their red cells and all patients taking 10 or more million units had large amounts of the drug on their cells. In patients who have developed a high titre of IgG antibodies to benzylpenicilloyl haemolytic anaemia occurs as a consequence of the reaction of these antibodies with the drug attached to the red cells (Levine, Fellner, and Levytska, 1966). Hapten inhibition experiments have indicated that only benzylpenicilloyl-specific antibodies are involved in this type of immune haemolytic anaemia (Levine et al, 1966). The antibodies thus appear not to react with antigenic determinants on the red cell. Very similar pathogenetic events seem to be operative in cephalothin-(Keflin) induced haemolytic anaemia (Gralnick, McGinnis, Elton, and McCurdy, 1971). The red cell appears to be damaged by cephalothin bound onto its surface and is then destroyed following the union of circulating anticephalothin antibody with the antigen. For clinical purposes it is important to know that the incidence of penicillin-induced haemolytic anaemia is much commoner than that of cephalothin-induced anaemia and ranks at the top of a series of some 15 drugs incriminated in immune red cell damage (review in Miescher, 1973).

More recently, it has been shown that cephalothin can lead to thrombocytopenia. Gralnick, McGinnis, and Halterman (1972) were able to detect a cephalothin-specific antibody in a well studied patient suffering from cephalothin-induced thrombocytopenia. When cephalothin was added to the patient's platelets, her serum agglutinated her in-vitro cephalothincoated platelets but not her own uncoated platelets. This activity could be neutralized by prior incubation of the serum with cephalothin. This latter experiment distinguishes this type of mechanism from the immune complex type of damage in which a preformed complex produces agglutination (Pfueller and Lüscher, 1972).

\section{Drug-induced Autoimmune Phenomena}

The association of certain drugs, eg, hydralazine, procainamide, with antinuclear antibodies has lead to the assumption that the two events are causally related (Perry and Schroeder, 1954; Blomgren, Condemi, Bignall, and Vaughan, 1969). Indeed, when procainamide medication is discontinued in patients taking this drug and exhibiting an SLE-like syndrome, antinuclear antibody and clinical symptoms and signs of SLE gradually disappear (Blomgren et al, 1969). Subsequently, this observation was extended to other autoantibodies as well and in particular to antibodies directed against antigenic determinants located on the membrane of red cells.

Indeed, with the introduction of methyldopa into the treatment of hypertension, this mechanism was firmly established. In fact, about $20 \%$ of patients receiving this drug for many months have been shown to develop a positive IgG Coombs test which is due to antibodies specific for the $R h$ locus (Carstairs, Breckenridge, Dalleny, and Worlledge, 1966; Eyster and Jenkins, 1970). This phenomenon, however, leads to overt haemolysis only in $1 \%$ of 
methyldopa-treated patients with a positive Coombs test (Worlledge, 1973).

Methyldopa does not participate in this reaction which, therefore, is due to an autoantibody whose production has been triggered by the drug. While this mechanism of drug-induced blood damage appears today well established, it is not yet possible to explain how the drug leads to autoimmunization. It has been suggested that the drug may alter the autologous antigen in such a way that it becomes antigenic but there is no proof to substantiate this hypothesis.

\section{Serological Methods for the Detection of Drug-induced Allergic Blood Dyscrasias}

Erythrocytes lend themselves to serological studies much more than platelets or leucocytes. It is easy to prepare a suitable red cell suspension which does not lead to intrinsic cell-to-cell interactions. Therefore, red cells are frequently used as an indicator system in a great variety of immunological reactions where the endpoint is either haemolysis or agglutination.

In contrast, both granulocytes and thrombocytes are activated by a variety of physiological phenomena which may lead to an increase in oxygen consumption and enzyme release. Any surface activation may lead to agglutination of the cells and, in the case of platelets, to viscous metamorphosis and thus the process may be mistaken for 'immune-agglutination' or 'immune-lysis'. This susceptibility of leucocytes and platelets to surface activation from nonimmunological causes limits their usefulness in serological procedures.

\section{RED CELLS}

The classical serological reactions with red cells are based on the antiglobulin test (review in Mollison, 1967). Some drug-dependent immune reactions produce a positive anti-immunoglobulin or anti-complement test when the reaction mixture contains the drug-specific antibody, the drug, the red cells and fresh serum (Harris, 1956). In the immune complex type of reaction, washing of red cells removes the drug as well as the antibody, leaving only complement on the surface of the red cells and thus tests with anti-immunoglobulin will be negative and the cells will only be agglutinated with anti-complement. When the drug is attached to the red cell, both tests may be positive since the antibody will resist washing if the attachment if firm enough. Finally, in the case of penicillin, the best results are obtained if red cells are previously coated with the drug. Anti-immunoglobulin and anti-complement tests are therefore still the most frequently used systems for assessment of both drug-antibody complex and drug-coating injury to red cells.

\section{PLATELETS}

Various in-vitro methods for the detection of drugplatelet immune reactions have been developed but agglutination techniques are still the most frequently used. A positive test with negative controls and inhibition experiments (Gralnick et al, 1972) is essential before the drug is incriminated as a possible aetiological agent of thrombocytopenia. Since none of these tests gives complete information on the pathogenesis of a given reaction, these studies may be combined with in-vivo tests to measure the survival time of radioactive-labelled autologous platelets in treated patients.

In the Sedormid type of thrombocytopenia, the reaction mixture of drug-specific antibody, drug and platelets may produce agglutination strong enough to be easily distinguished from non-specific clumping (Ackroyd, 1964). Furthermore, in some patients with this type of thrombocytopenia, the addition of the drug to the citrated blood will result in an inhibition of clot retraction after recalcification. One of the most sensitive tests is probably the complement fixation test with the patient's serum, platelets and the offending drug, but anti-HL-A alloantibodies may lead to 'false'-positive results. Other methods which have been proposed for the detection of drugdependent platelet reactions in the serum are platelet factor III release (Karpatkin, 1971), $\alpha$-aminonitrogen generation (Nachman and Engle, 1963) and serotonin-uptake inhibition (Davis and Wilson, 1964). None of these methods is suitable as a routine laboratory test.

\section{LEUCOCYTES}

Only a few in-vitro techniques are available for testing drug damage to leucocytes. Moeschlin and Moreno (1954) have shown that, in the case of amidopyrine, the patient's serum may for a limited time after drug exposure agglutinate leucocytes, presumably because of circulating immune complexes (Miescher, 1955). In other cases, agglutination of leucocytes may occur when a drug-specific antibody reacts with the cells in the presence of the drug. Leucoagglutinins, occurring during the acute phase of agranulocytosis, have also been described with dipyrone (Huguley, 1964) and phenylbutazone (Weissmann and Xefteris, 1959).

One of the most reliable tests is probably the complement-fixation test with the patient's serum, leucocytes and the offending drug. As in the case of platelets, HL-A-dependent complement fixation has to be ruled out. 


\section{SPECIAL TESTS FOR THE DETECTION OF ALLERGIC DRUG REACTIONS}

It must be stressed that the demonstration of drugdependent leucocyte and platelet serum factors is still the exception. Therefore, it is not surprising that a great variety of techniques have been described for this purpose. Tullis (1958) has reported a leucolytic test which involves counting the leucocytes before and after incubation with the offending drug. Furthermore, blast transformation (Halpern, Ky, Amache, Lagrue, and Hazard, 1967) and in-vitro thymidine uptake by lymphocytes in the presence of drugs have been used (Holland and Mauer, 1965). Other techniques based on cell function, such as oxygen consumption, phagocytosis and serotonin release. Unfortunately, none of these procedures is suitable as a routine diagnostic test.

\section{Conclusion}

Although drug-induced allergic blood dyscrasias occur with increasing frequency in proportion to the consumption of drugs, it is still difficult to make an accurate diagnosis in the individual case. All too often, the diagnosis remains presumptive and serologically proven cases are exceptional. As a matter of fact, each time that it has been possible to reveal the underlying mechanisms, there has been a special report to mark this unusual event. Nevertheless, it is hoped that further investigation will not only facilitate diagnosis but also teach us more about the pathogenesis of the various types of drug-induced immune cell damage.

\section{References}

Ackroyd, J. F. (1964). The diagnosis of disorders of the blood due to drug hypersensitivity caused by an immune mechanism. In Immunological Methods, edited by J. F. Ackroyd, Blackwell, Oxford.

Blomgren, S. E., Condemi, J. J., Bignall, M. C., and Vaughan, J. H. (1969). Antinuclear antibody induced by procainamide: A prospective study. New Engl. J. Med., 281, 64-66.

Carstairs, K. G., Breckenridge, A., Dollery, C. T., and Worlledge, S. M. (1966). Incidence of a positive direct Coombs' test in patients on $\alpha$-methyldopa. Lancet, 2, 133-135.

Cochrane, C. G., and Koffler, D. (1973). Immune complex disease in experimental animals and man. Advanc. Immunol., 16, 185-264.

Davis, J. W., and Wilson, S. J. (1964). Quinidine effect on platelet uptake and release of serotonin. Blood, 24, 841-842.

Eyster, M. E., and Jenkins, D. E., Jr. (1970). Gamma G erythrocyte auto-antibodies: comparison of in vivo complement coating and in vitro " $\mathrm{Rh}$ " specificity. J. Immunol., 105, 221-226.

Gillespie, E. (1971). Colchicine binding in tissue slices. Decrease by calcium and biphasic effect of adenosin- $3^{\prime}, 5^{\prime}$-monophosphate J. Cell Biol., 50, 544-549.

Gralnick, H. R., McGinnis, M., Elton, W., and McCurdy, P. (1971). Hemolytic Anaemia associated with cephalothin. J. Amer. med. Ass., 217, 1193-1197.

Gralnick, H. R., McGinnis, M., and Halterman, R. (1972). Thrombocytopenia with sodium cephalothin therapy. Ann. intern. Med., 77, 401-404.

Halpern, B., Ky, N. T., Amache, N., Lagrue, G., and Hazard, J. (1967). Diagnostic de l'allergie medicamenteuse "in vitro" par l'utilisation du test de transformation lymphoblastique. Presse med., 75, 461-465.

Harris, J. W. (1956). Studies on the mechanism of a drug-induced hemolytic anaemia. J. Lab. clin. Med., 47, 760-775.

Holland, P., and Mauer, A. M. (1965). Diphenylhydantoin-induced hypersensitivity reaction. J. Pediat., 66, 322-332.

Huguley, C. M., Jr. (1964). Agranulocytosis induced by dipyrone, a hazardous antipyretic and analgesic. J. Amer. med. Ass., 189, 938-941.

Karpatkin, S. (1971). Drus-induced thromb ytepeni the i.J. med. Sci., 262, 68-78.

Levine, B. B., and Redmond, A. P. (196i). Immune, lechanisms of penicillin-induced Coombs positivity in man (Abstr.) J. clin. Invest., 46, 1085.

Levine, B. B., Fellner, M. J., and Levytska, V. (1966). Benzylpenicilloyl-specific serum antibodies to penicillin in man. II Sensitivity of the hemagglutination assay method, molecular classes of the antibodies detected, and antibody titers of randomly selected patients. J. Immunol., 96, 719-726.

Mannik, M., Haakenstad, A. O., and Arend, W. P. (1974). The fate and detection of circulating immune complexes. Progr. Immunol., 5, 91-101.

Miescher, P. A. (1955). Leucopénies et agranulocytoses d'origine immunologique. Sang, 26, 71.

Miescher, P. A. (1973). Drug-induced thrombocytopenia. Semin. Haemat., 10, 311-325.

Moeschlin, S., and Moreno, R. (1954). Pyramidon-Agranulocytose mit 'Agglutininen für arteigene und artfremde Leukocyten. Klin. Wschr., 32, 799-802.

Moeschlin, S., and Wagner, K. (1952). Agranulocytosis due to the occurrence of leukocyte-agglutinins (pyramidon and cold agglutinins). Acta. haemat. (Basel), 8, 29-41.

Mollison, P. L. (1967). Blood Transfusion in Clinical Medicine, p. 432. Blackwell, Oxford.

Nachman, R. L., and Engle, R. L., Jr. (1963). Amino acid release following platelet-antibody interactions. Fed. Proc., 22, 673.

Nussenzweig, V., Lay, W. H., and Miescher, P. A. (1969). IgG- and $C^{\prime}$-dependent receptor sites on leukocytes. In Cellular Recognition, edited by R. T. Smith and R. A. Good. AppletonCentury-Crofts, New York.

Perry, H. M., Jr., and Schroeder, H. A. (1954). Syndrome simulating collagen disease caused by hydralazine (Apresoline). J. Amer. med. Ass., 154, 670-673.

Pfueller, S. L., and Lüscher, E. F. (1972). The effects of aggregated immunoglobulins on human blood platelets in relation to their complement-fixing abilities. I. Studies of immunoglobulins of different types. J. Immunol., 109, 517-525.

Shulman, N. R. (1958). Immunoreactions involving platelets. I. A steric and kinetic model for formation of a complex from a human antibody, quinidine as a haptene, and platelets; and for fixation of complement by the complex. J. exp. Med., 107, 665-690.

Shulman, N. R. (1963). Mechanism of blood cell destruction in individuals sensitized to foreign antigens. Trans. Ass. Amer. Physcns., 76, 72-83.

Tullis, J. L. (1958). Prevalence, nature and identification of leukocyteantibodies. New Engl. J. Med., 258, 569-578.

Weissmann, G., and Xefteris, E. D. (1959). Phenylbutazone leukopenia. Arch. intern. Med., 103, 957-961.

Worlledge, S. M. (1973). Immune drug-induced hemolytic anemias. Semin. Haemat., 10, 327-344. 